\title{
Longitudinal and temporal variations of density and size structure of Corbicula fluminea (Bivalvia) populations in the Saône and Rhône rivers (France)
}

\author{
J. Mouthon \\ Cemagref, 3 bis quai Chauveau, CP 220, 69336 Lyon cedex 09, France. E-mail : jacques.mouthon@ cemagref.fr
}

\begin{abstract}
Corbicula fluminea populations were sampled annually from 1997 to 2000 at the beginning of the autumn, i.e. at the end of the reproduction period, at 14 sites along the Saône and Rhône rivers. Recruitment in the upper reach of these rivers was generally high. Conversely, the observation of other sectors revealed generally low or no production of juveniles, missing cohorts and major year to year variations in population structure. Nevertheless, no dramatic fall in population density was observed during the surveyed four years. This suggests that the longevity of the Corbicula populations of the Saône and Rhône rivers is ensured to a great extent by the drifting of individuals from the upper course of these rivers and their tributaries. Two possible causes are put forward to explain the low recruitment observed : low production of phytoplankton that prevents adults from constituting sufficient energy reserves to ensure the full development of larvae, and/or toxic contamination, which inhibits the development of phytoplankton and it is lethal for pediveligers.
\end{abstract}

Keywords : Corbicula fluminea, Asian clam, size composition demography, Rhône and Saône rivers.

\section{Introduction}

Corbicula is known to feed above all on phytoplankton and seston (Foe \& Knight 1985, 1986, Lauritsen 1986, Leff et al. 1990, Boltovskoy et al. 1995). However, individuals are capable of pedal-feeding; the cilia at their foot allowing them to collect organic material from the sediment (Way et al. 1990, Reid et al. 1992). Corbicula use the ingested food to assure their growth and constitute the energy reserves required to develop embryos that feed from the secreting cells of the adults' internal branchiae (Britton \& Morton 1982). Therefore the level of recruitment strongly depends on the quantity of food available (Kraemer \& Galloway 1986, Williams \& McMahon 1986, 1989, Doherty et al. 1987, Cataldo \& Boltovskoy 1999).

In the Sacramento-San Joaquim Delta (California, USA), Foe \& Knight (1985) estimated the growth-limiting concentrations of chlorophyll a at approximately $20 \mu \mathrm{g} \mathrm{L}^{-1}$ in spring, and $47.3 \mu \mathrm{g} \mathrm{L}^{-1}$ in summer. Furthermore, Hakenkamp \& Palmer (1999) showed that growth of Corbicula was optimal when both modes of nutrition, filter-feeding and pedal-feeding, were used. In the Saône River at Lyon and the Haut-Rhône River at Creys-Malville (France), the study of the biological cycle and the dynamics of Corbicula fluminea populations carried out from 1996 to 1999 drew a parallel between the low growth of these bivalves whose longevity is 5 years instead of the 1.5 to 3 years generally observed (Lévêque 1973, Morton 1977, Aldridge \& McMahon 1978, Eng 1979, McMahon \& Williams 1986, Williams \& McMahon 1986, Dubois 1995) and the low production of phytoplankton measured at these two sites (Mouthon 2001ab). In spite of the rather unfavourable trophic conditions found in the Rhône and most of the Saône (Agence de l'eau RMC 1999, Fruget $\&$ Persat 2000), both these rivers have been substantially colonized by Corbicula since the 1990's (Mouthon 2000). The objective of this article is to describe the longitudinal and temporal variations of Corbicula populations and their size structure in the Rhône and Saône over 4 years, in order to provide better understanding of their dynamics. 


\section{Material and methods}

Corbicula were collected in 14 sites along the Saône and Rhône rivers, every year from 1997 to 2000 at the beginning of autumn (the last week of September or the first week of October), i.e. at the end of the reproduction period (Fig. 1). However, due to the low densities observed during the first three years, the sites located in the bypass sections of the Saône (Gray, Pontailler) and Rhône (Vernaison, Tournon) were not prospected in 2000. Sampling $\left(1 / 4 \mathrm{~m}^{2}\right)$ was carried out at four emplacements at a depth ranging from 0.50 to $1.5 \mathrm{~m}$, using a rectangular hand-net $(25 \times 18 \mathrm{~cm})$; the total area sampled was $1 \mathrm{~m}^{2}$. The samples were fixed on-site in $12 \%$ neutralised formaldehyde and sieved at $450 \mu \mathrm{m}$ in the laboratory.

The shell length (SL, greatest anterior-posterior dimension across the valves) of individuals $>5 \mathrm{~mm}$ was measured with a dial calliper to the nearest $0.1 \mathrm{~mm}$ and individuals $<5 \mathrm{~mm}$ with an eye piece micrometer at $25 \mathrm{x}$ under a binocular microscope. All individuals were divided into $1 \mathrm{~mm}$ size classes, then the size histograms were analysed using Bhattacharya's (1967) graphical method available in the FiSAT software distributed by FAO-ICLARM (Gayanilo et al. 1996). For each cohort, the mean size of the individuals and the standard deviation were calculated. Chlorophyll data were supplied by the Rhone, Mediterranean, Corsica Water Agency.

\section{Results}

\section{Density}

The Corbicula sampled belonged to two distinct forms grouped under the terms white form or light colored shell morph or form A by Hillis \& Patton (1982). The Saône specimens, like those encountered in the French river system, have a brown colored periostracum and nacre with purple highlights inside the shell. The juveniles have three violet pigmented zones, one central and two lateral. However, in the Rhône upstream of Lyon, most individuals observed had a yellowish periostracum and an off-white nacre (Mouthon 2000). In juvenile individuals, the pigmented zones were either absent or scarcely apparent. Downstream of Lyon, these two forms coexisted, though the proportion of yellow individuals decreases progressively as the river continues its course (Fig. 2).

The highest densities of Corbicula (Fig. 3) occurred in the upper reach of the Saône (Port/S) and downstream of its confluence with the Doubs (Ouroux). The flood at the end of September 1998 explained the low abundances observed in this part of the Saône (Port/S, Pontailler, Gray). On the contrary, this flood also affected the Saône's main tributaries, the Ognon and the Doubs, both largely colonized by Corbicula, and led to an increase in population density downstream of their respective confluences at Allériot and above all at $\mathrm{Ou}-$ roux, where the population of Corbicula grew by a factor of 2 from 1997 to 1998.

At Port/S, juveniles (mean first cohort $\mathrm{SL} \leq 1.75$ mm) made up the greater part of Corbicula from 1997 to 2000 . On the other hand, populations at the other sites were generally dominated by individuals aged one year or more.

Although densities fluctuated considerably from one year to another, Corbicula populations mostly composed of juveniles (mean first cohort SL $\leq 4.25$ $\mathrm{mm}$ ) were generally more abundant in the Rhône upstream than downstream of Lyon (Fig. 4). The greatest densities were recorded at Creys (1997 and 2000), Pont-de-Jons (1999) and Lyon (1999 and 2000). The dams at the entrance of the bypass sections of the Rhône, which substantially reduce the possibilities of colonization of these sectors by Corbicula, and the presence of toxic substances (Vernaison), were the most probable reasons for the very low abundances observed at Vernaison and Tournon. However, densities were higher at stations located in the navigated reaches of the river.

Populations of Corbicula were mostly composed of juveniles in the Haut-Rhône at Creys (except in 1998), Pont-de-Jons (1999) and Lyon (1999, 2000), in the lower course of the Rhône at Vernaison (1999), SaintAlban (1997 to 2000) and Donzère (1997, 1999). Populations of individuals aged one year and more were especially well represented at Creys (1998), Pont de Jons (1998 and 2000), Lyon (1997), Donzère (2000) and Aramon (1997).

\section{Population structure}

\section{Saône river}

4 cohorts were observed At Port/Saône at the beginning of autumn 1997. The first, which comprised the largest number of individuals, corresponded to the recruitment of the year during which the sampling was performed. The three other cohorts, whose numbers decreased as the mean size of individuals increased, were represented by increasingly older bivalves. This pyramidal population structure, also observed in 1998, 1999 and 2000, indicated that the life cycle of Corbicula at Port/S proceeded in a similar way throughout the four years concerned. Consequently, it was easy to 
estimate the increase of the mean size of the individuals of each cohort from one year to the next (Fig. 5).

However, this pyramidal population structure was not observed at any of the 5 other sites studied, whatever the year considered. At Pontailler in 1997 and 1998, and at Allériot in 2000, recruitment was nil or too low to statistically define a cohort, and in most

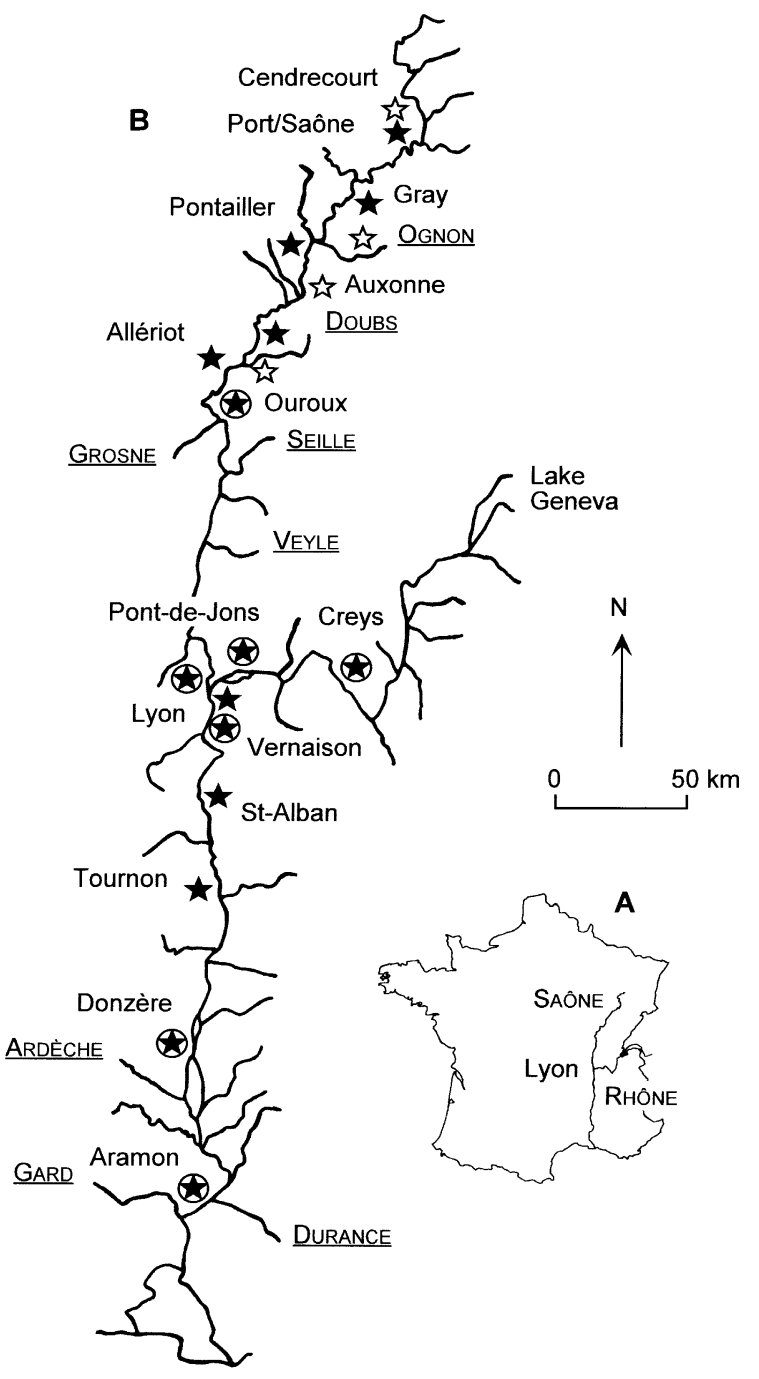

Mediterranean Sea

Fig. 1. A- Location of the Saône and Rhône rivers in France. B- The Saône and Rhône rivers and their main tributaries, with location of the sampling sites : Corbicula samples (black stars), chlorophyll and Corbicula samples (circled black stars), chlorophyll samples only (white stars). cases the number of juveniles was lower than $100 \mathrm{ind} / \mathrm{m}^{2}$, suggesting the probable absence or premature disappearance of this cohort in the forthcoming years, which is what was observed at Gray in 1998. Nevertheless, a more frequent observation was that the cohort no longer present the second year reappeared the following years. Moreover at Ouroux in 1997 and 1998 , this cohort was composed of a large number of
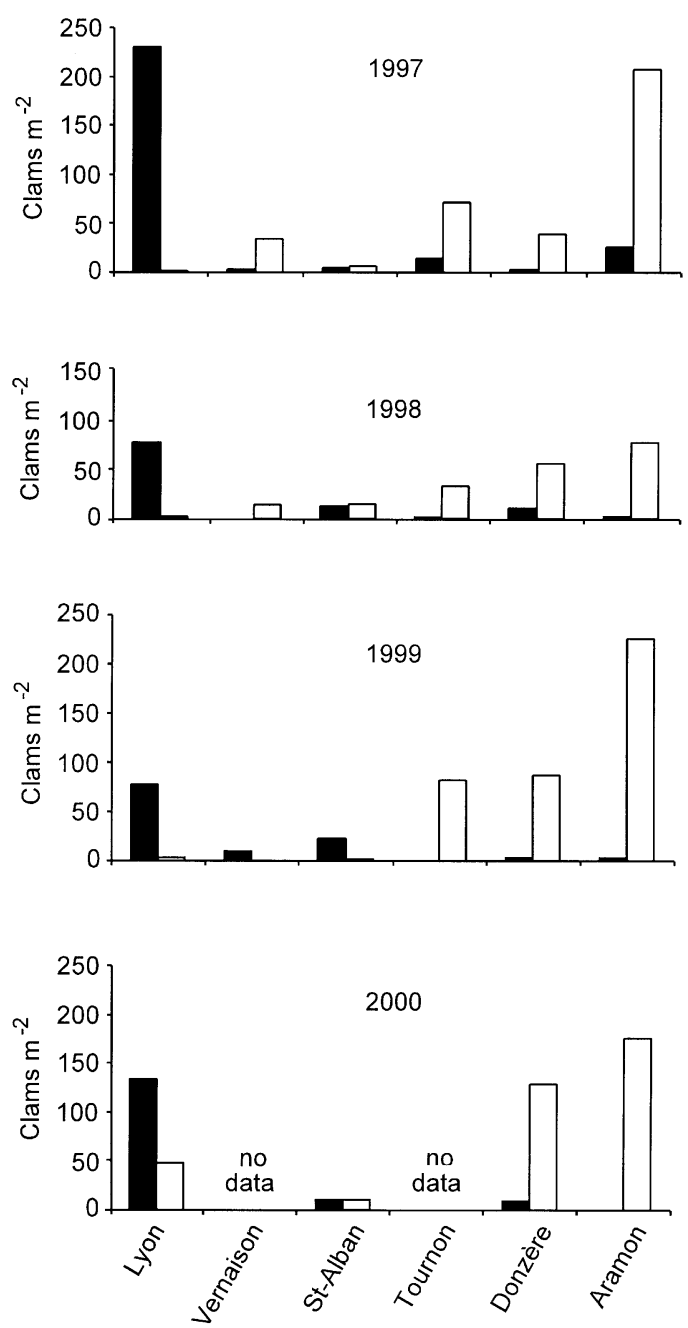

Fig. 2. Abundances of the two Corbicula forms (SL( 5) $\mathrm{mm}$ in the Rhône river downstream of Lyon at the beginning of autumn from 1997 to 2000. Black bars: Haut-Rhône form, white bars : Saône river common form. 


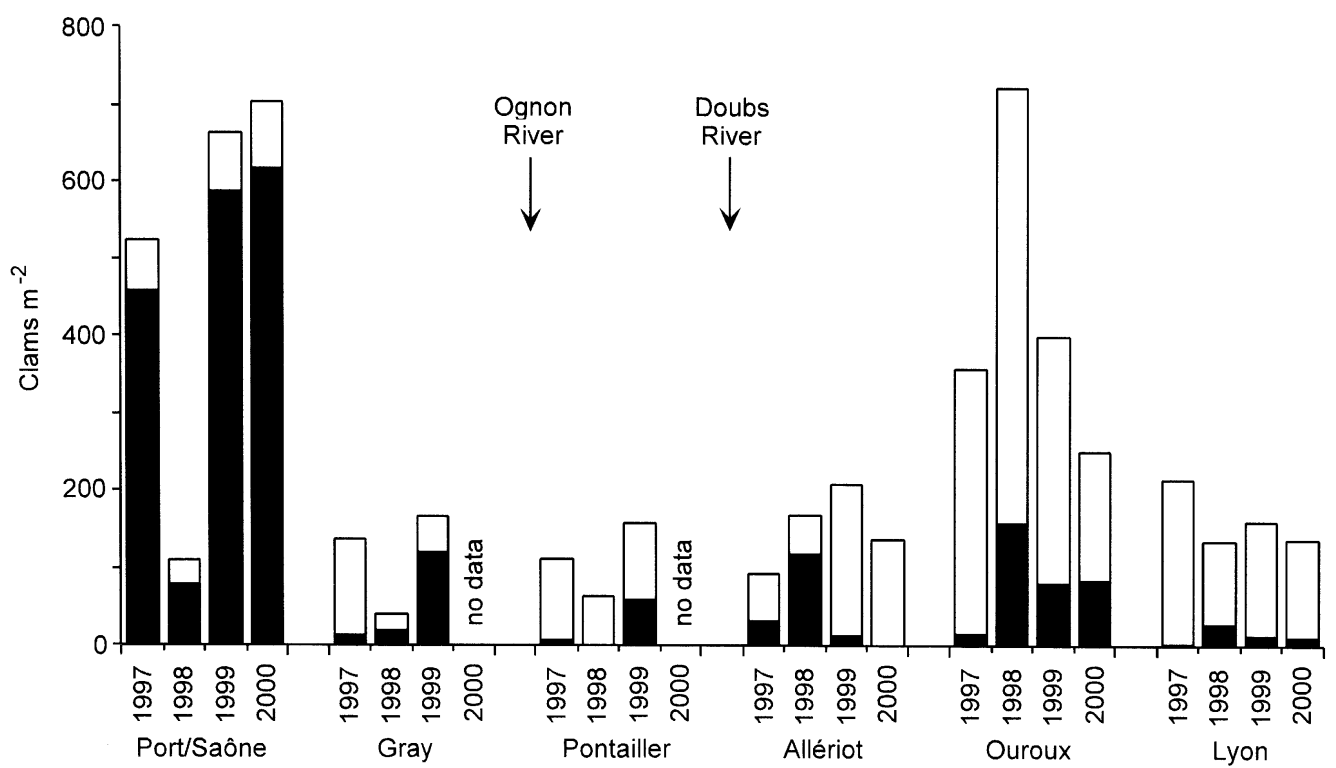

Fig. 3. Annual variations in the densities of Corbicula populations of 6 sites in the Saône river. Black : numbers of individuals from the first cohort.

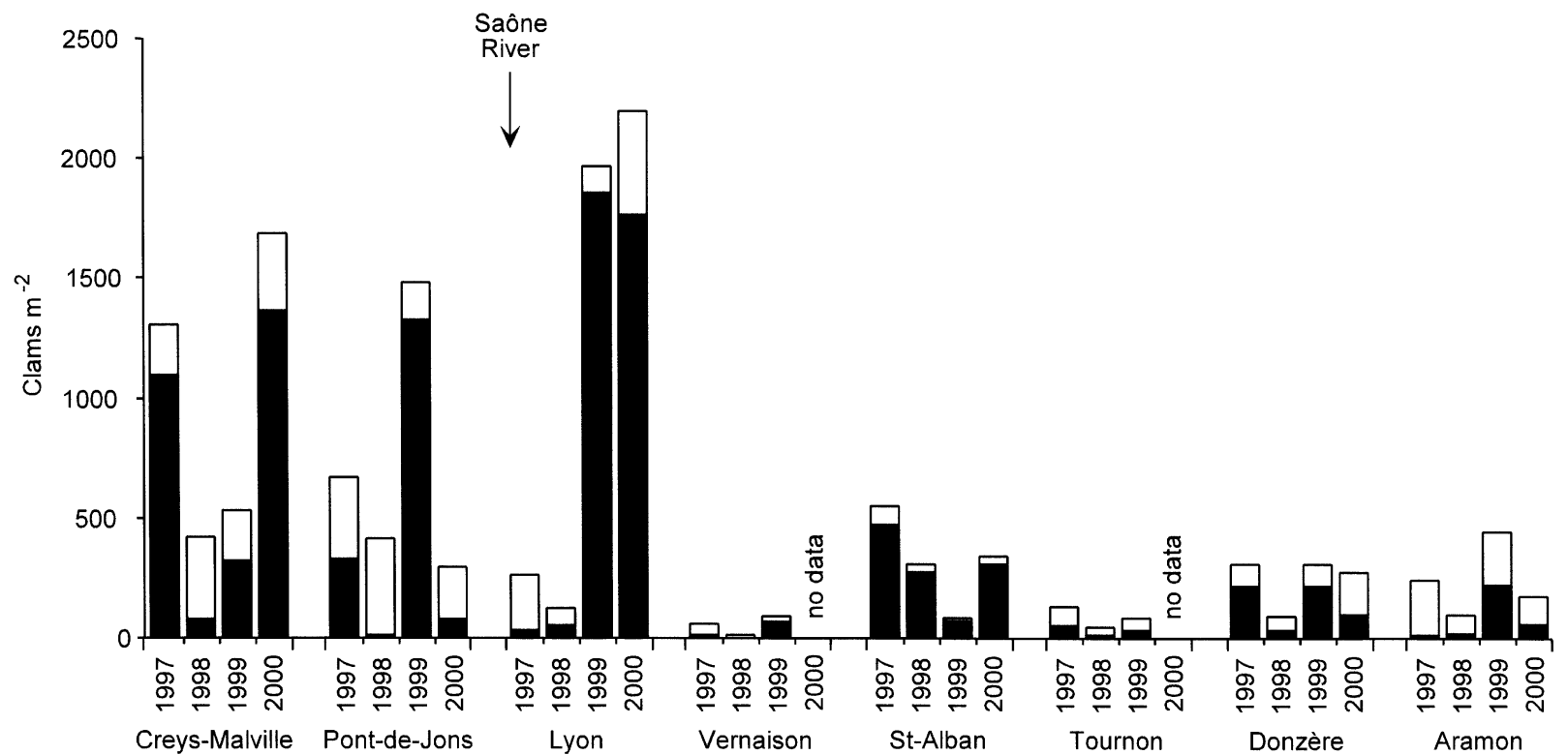

Fig. 4. Annual variations in the densities of Corbicula populations of 8 sites in the Rhône river. Black : see legend to Fig 3. 

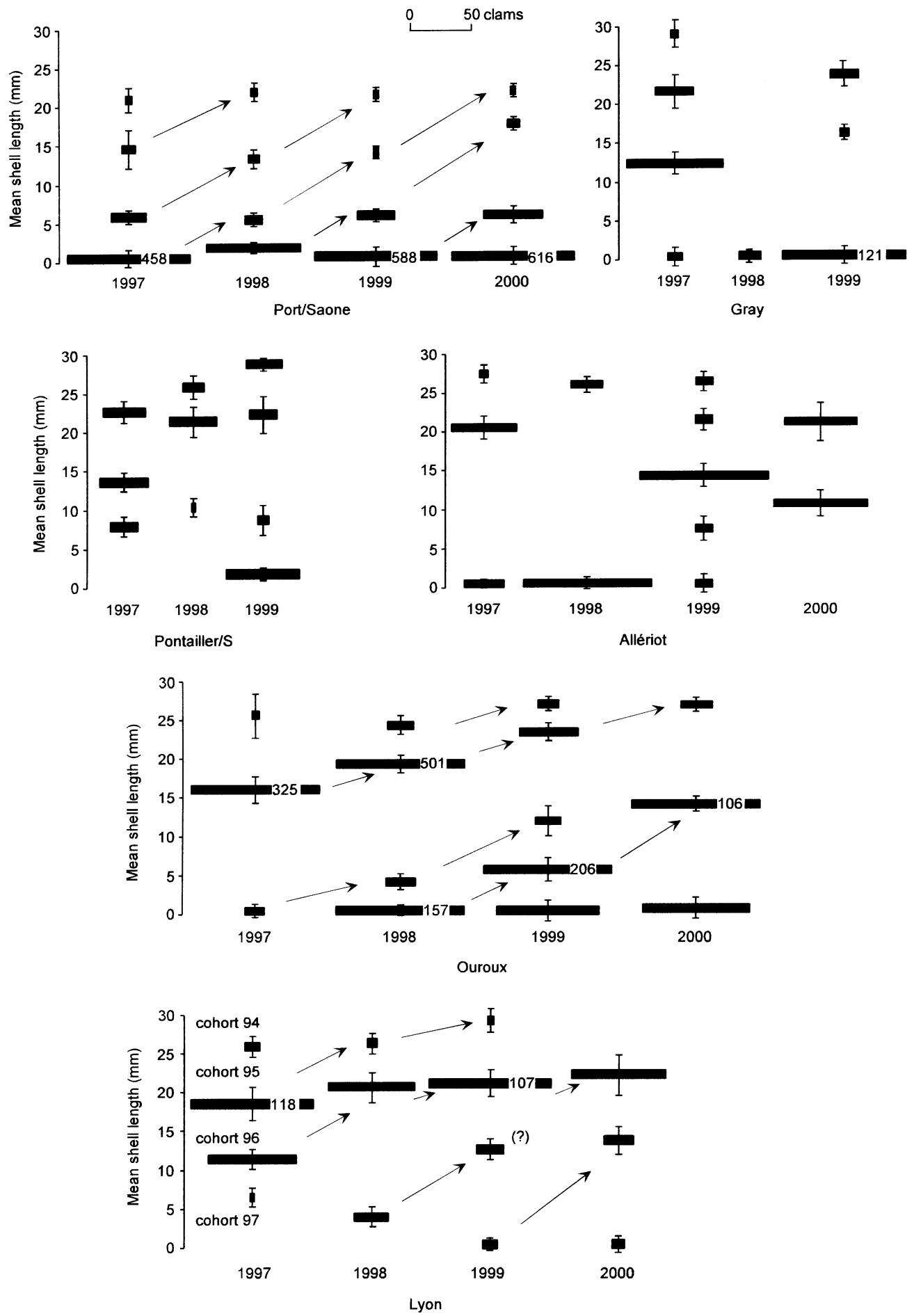

Fig. 5. Abundances and mean cohort shell lengths (horizontal bars) in annual samples from the 6 sites in the Saône river from 1997 to 2000. The vertical bars are standard deviations. 

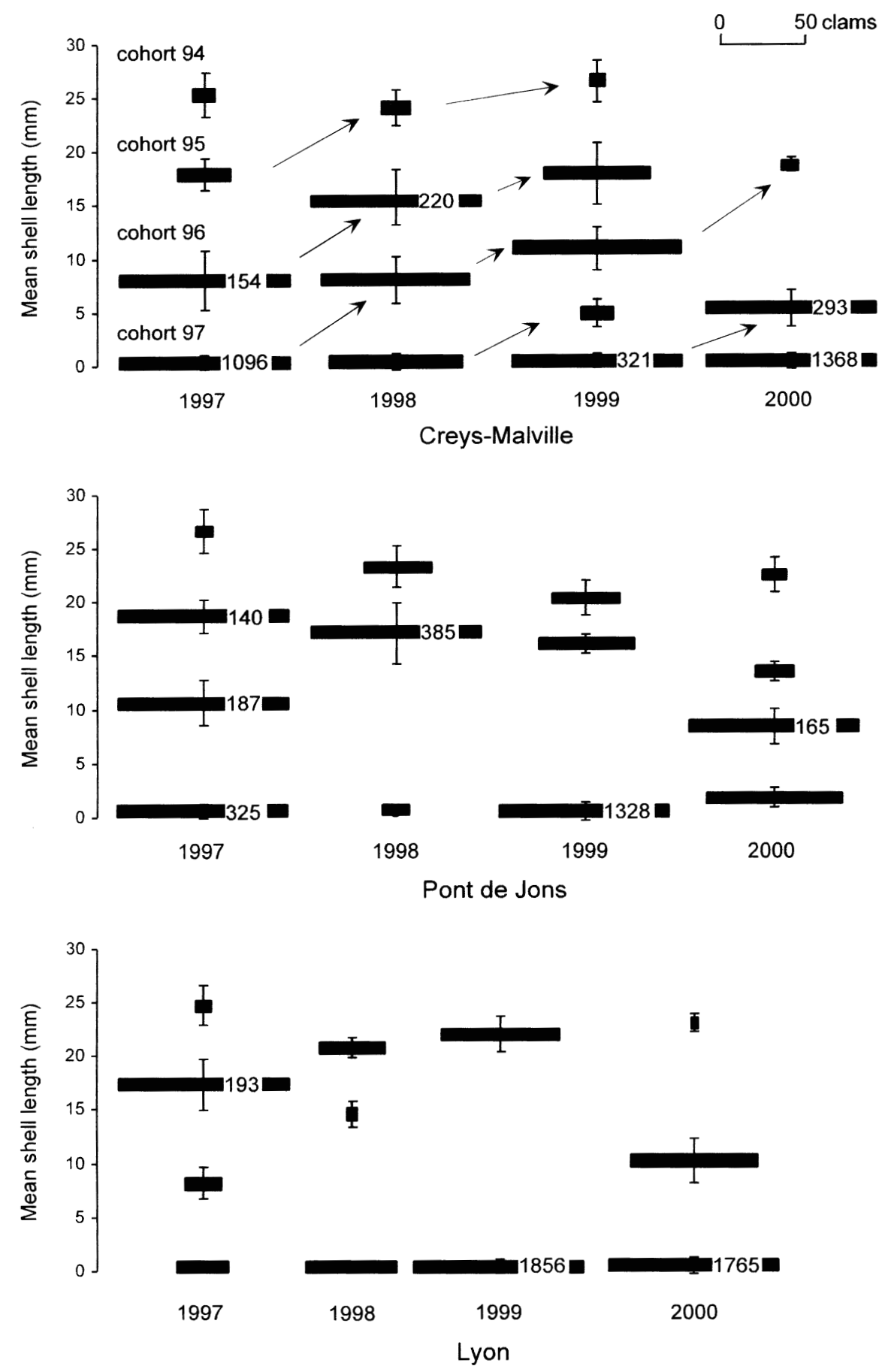

Fig. 6. Abundances and mean cohort shell lengths (horizontal bars) in annual samples from the 8 sites in the Rhône river from 1997 to 2000 . The vertical bars are standard deviations. 

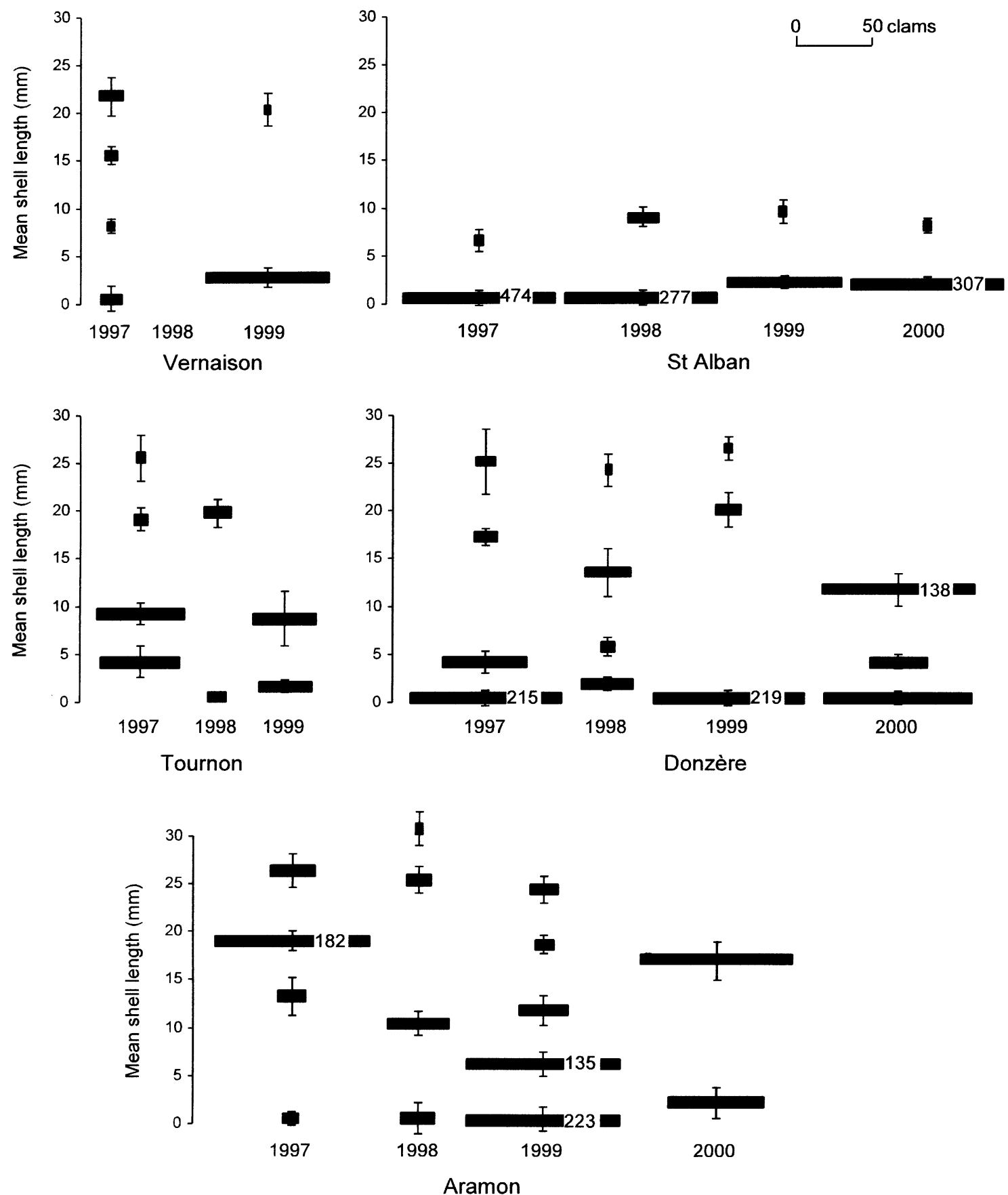

Fig. 6. (continued). Abundances and mean cohort shell lengths (horizontal bars) in annual samples from the 8 sites in the Rhône river from 1997 to 2000. The vertical bars are standard deviations. 
older individuals. Therefore estimating the increase of the average size of the individuals of a cohort over several years (Fig. 5) was only possible in rare cases, such as at Ouroux. At Lyon, where Corbicula have been studied since September 1996, the proposed succession of cohorts was established on the basis of monthly surveys (Mouthon, 2001a).

\section{Haut-Rhône (upstream of Lyon)}

At Creys-Malville, the life cycle of Corbicula fluminea was subjected to in-depth study (Mouthon 2001b). The presence of 5 cohorts was observed at the beginning of autumn 1999, 4 in 1997 and 1998 and only 3 in 2000 (Fig. 6). Indeed, the fall in the water level $(-1.5 \mathrm{~m})$ in June 2000 , following the drainage of the Verbois dam located upstream, led to the disappearance of cohort 98 whose recruitment had been particularly low. The pyramidal structure of the populations observed in 1997 was not repeated in 1998 and 1999; one of the cohorts was missing in 2000.

At Pont-de-Jons and Lyon, two to four cohorts were present depending on the year. Cohorts 97 and 98 disappeared the year following their appearance; they were represented once again in 1999 and 2000 at Pontde-Jons and in 2000 at Lyon where the eldest individuals probably constituted the vestiges of cohort 97 . However, a pyramid population structure was seen only at Pont-de-Jons in 1997, the same year as at Creys.

\section{Bas-Rhône (downstream of Lyon)}

With the exception of Vernaison, where it was not possible in 1998 to statistically define a cohort due to the very low number of individuals collected, the Corbicula populations of five sites distributed along the Rhône downstream of Lyon comprised from two at five cohorts (Fig. 6). Each year the population at Saint-Alban was represented by juveniles and only two cohorts were present. It is therefore clear that these Corbicula neither develop nor reproduce at this site, whose populations are entirely supplied by drifting (Eng 1979, Rodgers et al. 1979, Boltovskoy et al. 1997, Payne et al. 1989). In the bypass sections of Vernaison and Tournon, the densities recorded were very low and the structure of Corbicula populations varied considerably from one year to the next. At Donzère, each year the populations were mostly composed of young individuals. However, at Aramon the Corbicula were mainly represented by individuals whose mean size was larger than 19 $\mathrm{mm}$ in 1997, then lower than $6.5 \mathrm{~mm}$ in 1999.

\section{Discussion}

In the Saône, except in 1998, when a flood occurred at the end of September, the highest levels of production of juveniles were observed at Port/S where chlorophyll contents were the highest each year (Fig. 7). On the contrary, at the other sites, where the production of phytoplankton remained low for still unknown reasons (possibly the presence of photosynthesis inhibiting substances (metals, HAPs, pesticides, etc.) and (or) the instantaneous consumption of phytoplankton (Fruget \& Persat 2000)), the numbers of juveniles were very low and sometimes nil, although many larvae were present from June to September in the internal branchiae of the adults (Mouthon, 2001a). Nonetheless, in spite of these unfavourable trophic conditions, the numbers of Corbicula did not fall dramatically downstream of Port/S during the four years concerned. Furthermore, at the sites of Allériot, Ouroux and Lyon, numerous individuals belonging to cohorts rarely or not seen at all during previous years appeared frequently. The populations of the Saône therefore benefited from substantial arrivals of individuals from the upper course of this river and above all its tributaries, such as the Ognon, Doubs, Grosne, Seille and Veyle in which these bivalves proliferate (Mouthon 2000).

In the Haut-Rhône, the disappearances and reappearances of cohorts observed at Pont-de-Jons and Lyon also suggested that numerous individuals drift downstream, especially during the floods of June and July due to thawing snow.

In the Rhône downstream of Lyon where Corbicula belonging to the common form dominate (Fig. 2), the same process was observed as for the Saône. Toxic substances are everpresent (Agence de l'eau RMC 1999) and the production of chlorophyll remained low, since the mean values were often far lower than $8 \mu \mathrm{g}$ $\mathrm{L}^{-1}$ (Fig. 7). Consequently, we assume that Corbicula feed little on phytoplankton but probably pedal-feed on organic matter in the streambed. In parallel, recruitment at the study sites was generally observed to be low. When the numbers of juveniles were abundant as at Saint-Alban, the total absence of adults from 1997 to 2000 indicated that these young stages, that do not develop at the site, came from upstream. These observations therefore showed that the populations of the BasRhône were mostly composed of individuals from the Haut-Rhône, as attested by the presence of its specific form as far as Aramon (Fig. 2) and above all from the Saône. Nonetheless, the existence of more favorable sectors for the production of phytoplankton (abandonned channel, bypass sections, discharges of warm wa- 

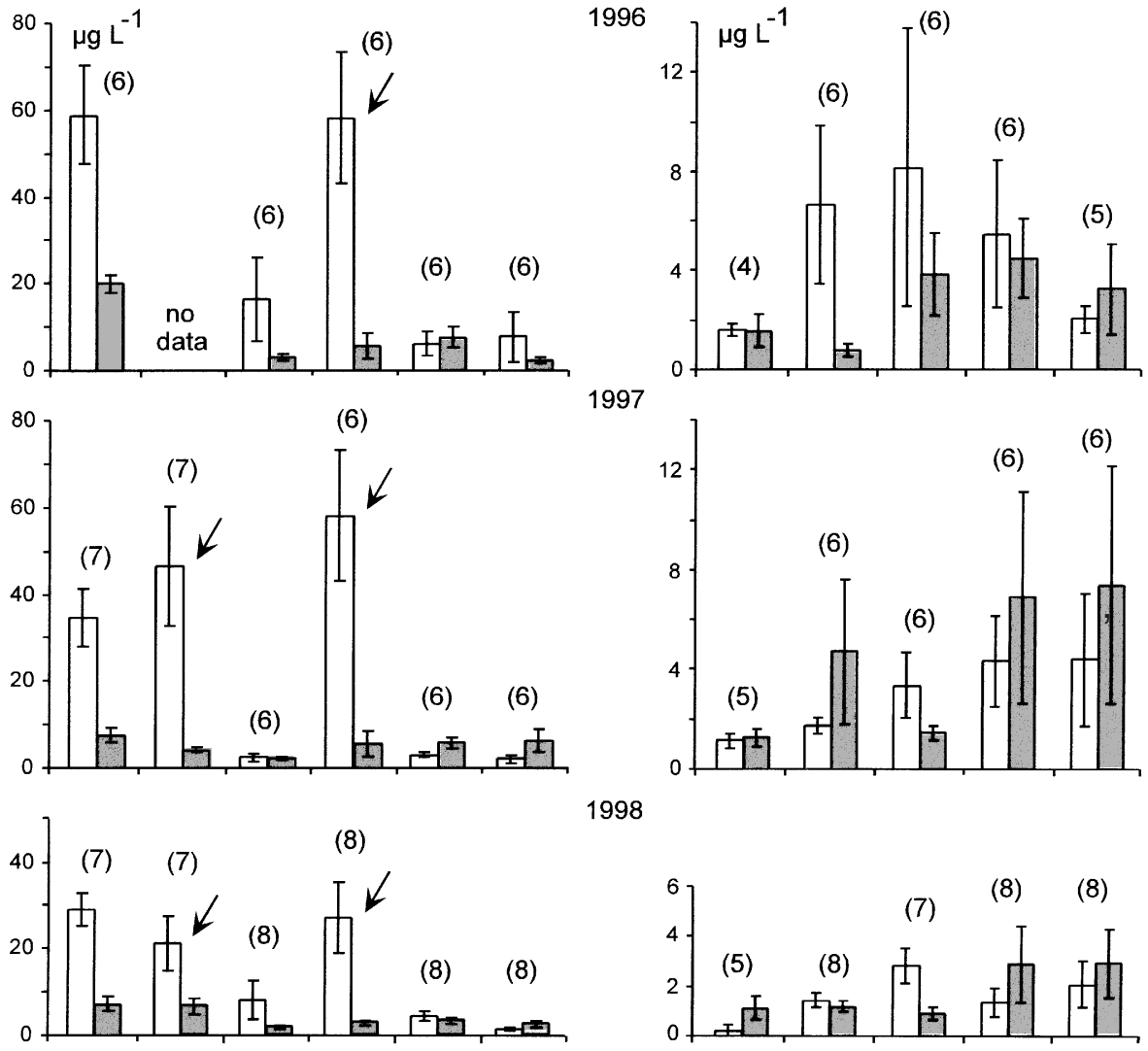

1998

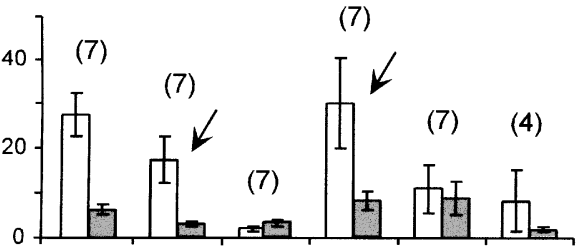

1999
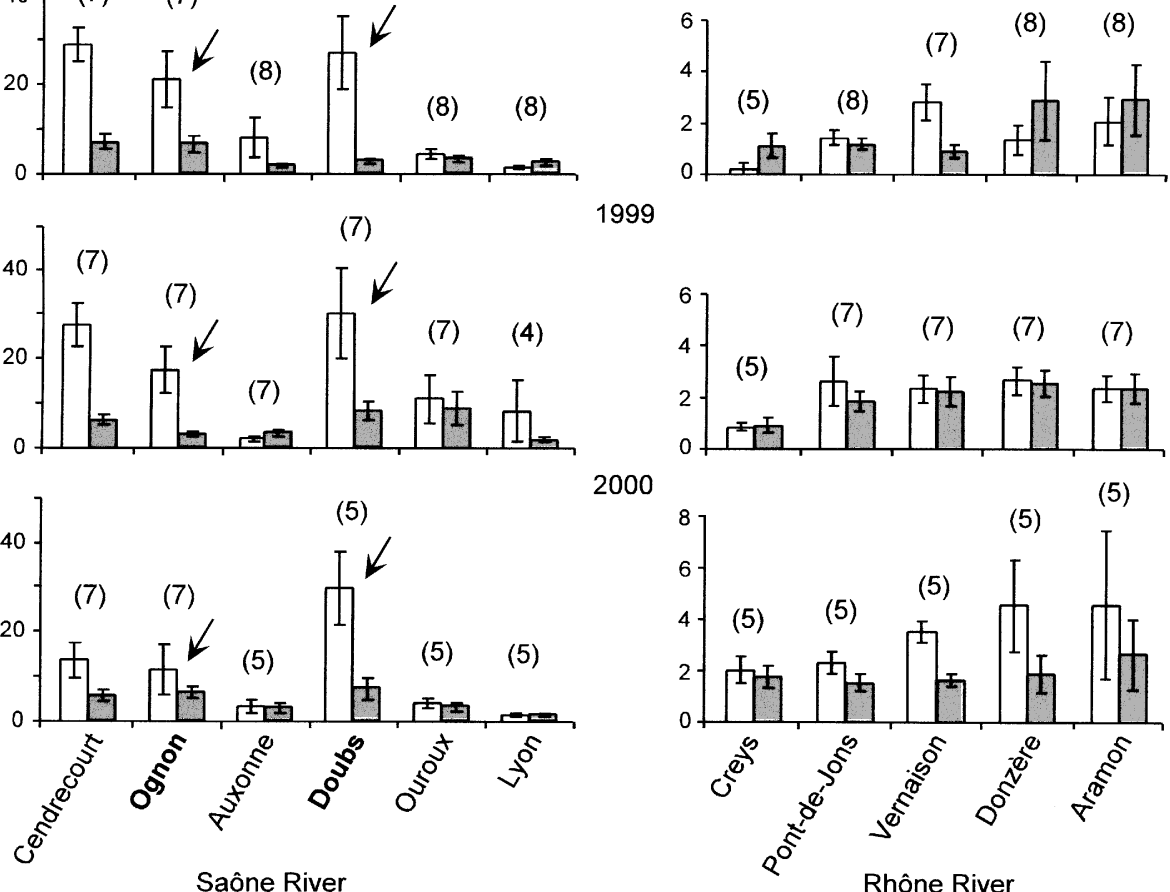

2000

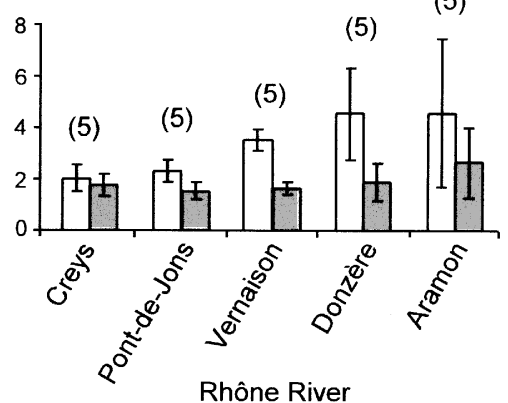

Fig. 7. Mean chlorophyll a (white) and phaeopigment (grey) concentrations measured from 1996 to 2000 in the Saône river and two main tributaries (in bold) indicated by arrows, and in the Rhône. Vertical bars are standard errors, ( ) : number of measurements. Note the different scale in the vertical axis between the Saône and Rhône rivers. (Creys : Cemagref data, others sites : RMC Water Agency data). 
ter from nuclear power plants) and thus for the reproduction of Corbicula cannot be neglected. What is more, populations recently settled in the lower reaches of the rivers Ardèche, Gard and Durance, respectively in 1998 and 1999 (Mouthon, 2000), may also contribute to the populations of the Bas-Rhône.

The longevity of Corbicula populations of the Saône downstream of Port/S and the Rhône downstream of Lyon is therefore largely ensured by individuals recruited from upstream by drift. The passive hydrological transport of pediveligers and juveniles suspended in the water column plays a major role in the dispersion of this bivalve in rivers (Williams \& McMahon 1986, McMahon 2000). However, adults can also be transported downstream by the current by the secretion of a long mucus dragline allowing them to float between two water levels (Prezant \& Chalermwat 1984) or over the surface of the substratum during floods (Eng 1979, Boltovskoy et al. 1997). Furthermore, according to Williams \& McMahon (1986, 1989) poor nutritional conditions favor adult dispersal.

Finally, substantial recruitment mainly occurs in the upper course of the Saône (Port/S) and Rhône (CreysMalville, Pont-de-Jons and Lyon), although the number of juveniles released varied greatly from year to year. In the other reaches of these rivers, Corbicula populations were characterized by generally low or no production of juveniles, missing cohorts and considerable variations of population structure that do not facilitate estimating the increase of the mean size of the individuals of each cohort from one year to the next.

Two main causes can be proposed to explain the low recruitment observed. 1- Low phytoplankton production does not permit adults to constitute sufficient energy reserves for the larvae to develop completely. In the Saône and Bas-Rhône, where the common form of Corbicula predominates, the magnitude of recruitment seems closely linked to the production of phytoplankton. However, in the Rhône upstream of Lyon, in spite of very low chlorophyll concentrations (Fig. 7), adults released a substantial number of juveniles. Consequently, these populations are able of constituting the reserves required for the development of the larvae without needing the trophic contribution of phytoplankton. This does not appear to be the case of Corbicula in the Saône, whose condition index (IC) at Lyon is lower than that of populations of the HautRhône at Creys (Lecouturier 1997). These two forms of Corbicula which differ in color and shell characteristics (Mouthon 2000) and which are also genetically distant from each other according to Renard et al.
(2000), also have different capacities for assimilating available food. 2- The toxic contamination that inhibits phytoplankton development is lethal for pediveligers. Indeed, in the Parana River delta in Argentina where concentrations of phytoplankton are low all year $\mathrm{Ca}-$ taldo \& Boltovskoy (1999), the absence of juveniles in populations of Corbicula, in spite of the presence of larvae in the internal branchiae of adults, is linked to water pollution (Boltovskoy et al. 1997). Furthermore, although Corbicula is considered as «generally tolerant of exposure to toxic materials» (Doherty 1990), Belanger et al. (1990) have shown that juveniles were more sensitive to copper than adults. According to this second hypothesis, the low production of juveniles observed in the Saône and Bas-Rhône is probably due to the presence of toxic substances. However, when contamination is reduced, as in the Haut-Rhône, the number of juveniles released is high.

Consequently, additional research is required to identify the cause of low juvenile production by the populations of the Saône and the Bas-Rhône as well as the taxonomic status of the Corbicula of the HautRhône.

\section{Acknowledgements}

I thank O. Fontaine (Rhône, Mediterranean, Corsica Water Agency) for chlorophyll data.

\section{References}

Agence de l'Eau Rhône Méditerranée Corse, 1999. — Qualité des eaux du Rhône, évolution 1969-1995. Rapport, Lyon, 99 pp + annexes.

Aldridge D.W. \& McMahon R.F. 1978. — Growth, fecundity, and bioenergetics in a natural population of the Asiatic freshwater clam, Corbicula manilensis Philippi, from North Central Texas. J. Moll. Stud., 44 : 49-70.

Belanger S.E., Farris J.L., Cherry D.S. \& Cairns J. 1990. — Validation of Corbicula growth reductions induced by copper in artificial streams and natural rivers. Can. J. Fish. Aquat. Sci., 47 : 904-914.

Bhattacharya C.G., 1967. - A simple method of resolution of a distribution into Gaussian components. Biometrics, 23 : 115-135.

Boltovskoy D., Izaguirre I. \& Correa N. 1995. - Feeding selectivity of Corbicula fluminea (Bivalvia) on natural phytoplankton. Hydrobiologia, 312 : 171-182.

Boltovskoy D., Correa N., Cataldo D., Stripeikis J. \& Tudino M. 1997. - Environmental stress on Corbicula fluminea (Bivalvia) in the Parana River delta (Argentina), complex pollution-related disruption of population structures. Arch. Hydrobiol., 138 : 483-507.

Britton J.C. \& Morton B. 1982. - A dissection guide, field, and laboratory manual to the intoduced bivalve Corbicula fluminea. Malacol. Rev., suppl. 3, 82pp.

Cataldo D. \& Boltovskoy D. 1999. - Population dynamics of Corbicula fluminea (Bivalvia) in the Parana River Delta (Argentina) Hydrobiologia, 380 : 153-163. 
Doherty F.G. 1990. — The Asiatic clam, Corbicula spp., as a biological monitor in freshwater environments. Environ. Monit. Assess., $15: 143-181$.

Doherty F.G., Cherry D.S. \& Cairns J. 1987. - Spawning periodicity of the Asiatic clam Corbicula fluminea in the New River, Virginia. Am. Midl. Nat., 117 : 71-82.

Dubois C., 1995. - Biologie et démo-écologie d'une espèce invasive Corbicula fluminea (Mollusca, Bivalvia) originaire d'Asie, Etude en milieu naturel (canal latéral à la Garonne, France) et en canal artificiel. PhD Thesis, Toulouse III University, 147 pp.

Eng L.L. 1979. - Population dynamics of the Asiatic clam, Corbicula fluminea (Müller), in the concrete-lined Delta-Mendota Canal of central California. Pages 39-63 in Proceeding of the First International Corbicula Symposium. Britton J.C. (ed). Texas Christian University Research Foundation, Fort Worth, Texas.

Foe C. \& Knight A. 1985. - The effect of phytoplankton and suspended sediment on the Growth of Corbicula fluminea (Bivalvia). Hydrobiologia, 127 : 105-115.

Foe C. \& Knight A. - 1986. Growth of Corbicula fluminea (Bivalvia) fed artificial and algal diets. Hydrobiologia, 133 : 155-164.

Fruget J.F. \& Persat H. 2000. — Changement de l'équilibre hydrobiologique de la Basse Saône. Impact de l'eutrophisation et de la contamination toxique. Report - ARALEPBP \& UMR CNRS, Lyon. 78 pp.

Gayanilo F.C., Sparre P. \& Pauly D. 1996. — FAO-ICLARM stock assessment tools. Food and Agriculture Organization of the United Nations, Rome, Computed information series 8, pp 1-126.

Hakenkamp C.C. \& Palmer M.A. 1999. - Introduced bivalves in freshwater ecosystems, the impact of Corbicula on organic matter dynamics in a sandy stream. Oecologia, 119: 445-451.

Hillis D.M. \& Patton J.C. 1982. - Morphological and electrophoretic evidence for two species of Corbicula (Bivalvia, Corbiculidae) in North America. Am. Mdl. Nat., 108 : 75-80.

Kraemer L.R. \& Galloway M.L. 1986. — Larval development of Corbicula fluminea (Müller) (Bivalvia, Corbiculacea), an appraisal of its heterochrony. Am. Malacol. Bull., 4 : 61-79.

Lauritsen D.D. 1986. - Assimilation of radiolabeled algae by Corbicula. Pages 219-222 in Second International Corbicula Symposium, Prezant, R.S. (ed.). Am. Malacol. Bull., Special Edition 2.

Lecouturier E. 1997. - Ecologie comparée de deux populations de Corbicula fluminea (Bivalvia, Corbiculidae). DEA Thesis, University C. Bernard Lyon I - Cemagref. 32 pp.

Leff L.G., Burch J.L. \& McArthur J. V. 1990. — Spatial distribution, seston removal, and potential competitive interactions of the bivalves Corbicula fluminea and Elliptio complanata, in a coastal plain stream. Freshwat. Biol., 24 : 409-416.

Lévêque C. 1973. - Dynamique des peuplements, biologie et estimation de la production des mollusques benthiques du Lac Tchad. Cah. ORSTOM sér. Hydrobiol., 7 : 117-147.

Mattice J.S. \& Dye L.L. 1976. - Thermal tolerance of the adult Asiatic clam. Pages 130-135 in Thermal Ecology. 2. Esch G.W. \& McFarlane R.W. (eds).
McMahon R.F. \& Williams C.J. 1986. — A reassessment of growth rate, life span, life cycle and population dynamics in a natural population and field caged individuals of Corbicula fluminea (Müller) (Bivalvia, Corbiculacea). Pages 151-166 in Proceeding of the Second International Corbicula Symposium. Prezant, R.S. (ed.). Am. Malacol. Bull., Special Edition 2.

Morton B. 1977. - The population dynamics of Corbicula fluminea (Bivalvia, Corbiculacea) in Plover Cove Reservoir. Hong Kong. J. Zool., $181: 21-42$.

Mouthon J. 2000. — Répartition du genre Corbicula Megerle von Mühlfeld (Bivalvia, Corbiculidae) in France à l'aube du XXIème siècle. Hydroécol. Appl., 12 (1/2 : 135-146.

Mouthon J. 2001a. - Life cycle and population dynamics of the Asiatic clam Corbicula fluminea (Bivalvia, Corbiculidae) in Saone River at Lyon (France). Hydrobiologia, 452 : 109-119.

Mouthon J. 2001b. - Life cycle and population dynamics of the Asiatic clam Corbicula fluminea (Bivalvia, Corbiculidae) in Rhône River at Creys-Malville (France). Arch. Hydrobiol., 151 : 571-589.

Payne B.S., Hartfield P.D., McMahon R.F. \& Miller A.C. 1989. Variation in size demography of lotic populations of Corbicula fluminea (Müller). The Nautilus, 103 : 78-82.

Prezant R.S. \& Chalermwat K. 1984. - Flotation of the bivalve Corbicula fluminea as a means of dispersal. Science, 225 : 1491-1493.

Reid R.G.B., McMahon R.F., Foighil D.O. \& Finnigan R. 1992. Anterior inhalant currents and pedal feeding in bivalves. The Veliger, $35: 93-104$.

Renard E., Bachmann V., Cariou M.L. \& Moreteau J.C. 2000. Morphological and molecular differentiation of invasive freshwater species of the genus Corbicula (Bivalvia, Corbiculidae) suggest the presence of three taxa in French rivers. Mol. Ecol., 9 : 2009-2016.

Rodgers J.H., Cherry D.S., Dickson K.L. \& Cairns Jr., J. 1979. Elemental accumulation of Corbicula fluminea in the New River at Glen Lyn, Virginia. Pages 99-110 in Proceeding of the First International Corbicula Symposium. Britton J.C. (ed). Texas Christian University Research Foundation, Fort Worth, Texas.

Way C.M., Hornbach D.J., Miller-Way C.A., Payne B.S. \& Miller A.C. 1990. - Dynamics of filter feeding in Corbicula fluminea (Bivalvia, Corbiculidae). Can. J. Zool., 68 : 115-120.

Williams C.J. \& McMahon R.F. 1986. - Power station entrainment of Corbicula fluminea (Müller) in relation to population dynamics, reproductive cycle and biotic and abiotic variables (Texas). Pages 99-111 in Proceeding of the Second International Corbicula Symposium. Prezant R.S. (ed.). Am. Malacol. Bull., Special Edition 2,.

Williams C.J. \& McMahon R.F. 1989. - Annual variation in tissue condition of the Asian freshwater bivalve, Corbicula fluminea, in terms of dry weight, ash weigth, carbon and nitrogen biomass and its relationship to downstream dispersal. Can. J. Zool., 67 : 82-90. 